\title{
Melatonin in ICU delirium: shining light on the hormone of darkness
}

\author{
Lisa Burry ${ }^{1,2^{*}}$ (D), Romain Sonneville ${ }^{3,4}$ and E. Wesley Ely, 5,6,7
}

๑ 2022 Springer-Verlag GmbH Germany, part of Springer Nature

Delirium represents a form of acute brain dysfunction predictive of excess death and long-term cognitive impairment in critically ill patients $[1,2]$. For many years, we have wondered whether pharmacological doses of melatonin would help prevent the onset or mitigate the duration of this calamity in the life of our sickest patients. The data are growing to help us realize answers.

Melatonin is a pleiotropic neurohormone produced by the pineal gland during the hours of darkness [3]. Understanding of the pineal gland and the biological effects of melatonin has evolved from its historical conceptualization as the "tranquilizing organ" and the "seat of the soul" to knowledge of their pivotal role in the regulation of circadian rhythm. Melatonin is synthesized from tryptophan via a sequence of enzymatic reactions. The rate-limiting enzyme is $N$-acetyltransferase (AA-NAT) whose synthesis is promoted by darkness with its activity modulated by the suprachiasmatic nucleus in the hypothalamus. Darkness stimulates the pineal gland to secrete melatonin with peak concentrations of $\sim 100 \mathrm{pg} / \mathrm{mL}$ between 02:00 and 04:00 h, while strong light suppresses production.

Melatonin works as a hypnotic by accelerating sleep initiation and improving sleep maintenance and efficiency [3]. Unlike other hypnotics, melatonin causes no significant changes in sleep architecture, nor does it have hangover effects or abuse potential, nor has it been associated with delirium. Although sleep-wake cycle disturbances are not a diagnostic criterion for delirium, they are incorporated into delirium assessment tools with studies indicating sleep alterations are present in $75 \%$

\footnotetext{
*Correspondence: lisa.burry@sinaihealth.ca

${ }^{1}$ Departments of Pharmacy and Medicine, Mount Sinai Hospital, Toronto, Canada
}

Full author information is available at the end of the article of delirious patients [4]. Disturbances in the circadian pattern of melatonin secretion have been described in various critically ill populations [4-6]. Advances in our understanding of the association of delirium and devastating outcomes of critically ill patients has prompted the flurry of prevention trials with pharmacological and nonpharmacological interventions and more recently, these include melatonin or melatonin receptor agonists and strategies for sleep (e.g., reducing noise or light) [7].

In this issue of the journal, Wibrow et al. report the results of the large double-blind multicenter randomized Pro-MEDIC trial on the usefulness of prophylactic melatonin for delirium in intensive care unit (ICU) [8]. The study compared melatonin with placebo among 847 patients across 12 Australian ICUs. The primary outcome was the proportion of delirium-free assessments within 14 days or before ICU discharge, as assessed by the Confusion Assessment Method for ICU (CAM-ICU). Secondary outcomes were sleep quality and quantity, delirium and coma-free days, length of stay, mortality, adverse events, and use of rescue therapies for delirium and agitation (e.g., antipsychotics, physical restraint). Patients aged $\geq 18$ years with expected ICU stay of $\geq 72 \mathrm{~h}$ were randomized to enteral liquid melatonin $4 \mathrm{mg}$ or matched placebo $q H S$ until ICU discharge or up to 2 weeks. The authors found no difference between groups in the proportion of delirium-free assessments (melatonin $79.2 \%$ vs. placebo $80 \%, p=0.457$ ). This finding was consistent across all subgroups including age, gender, diagnostic category, and delirium risk. There was no difference for any secondary outcome including measures of sleep quality or quantity, as scored on Richards-Campbell Sleep Questionnaire (RCSQ) and Little's questionnaires, or delirium and coma-free days.

The authors should be commended for the execution of one of the largest pharmacological delirium prevention trials to date. The current trial ticks the boxes for

\section{Springer}


Table 1 ICU delirium prevention randomized trials with melatonin or melatonin receptor agonist

\begin{tabular}{|c|c|c|c|c|c|c|}
\hline Author year & ICU population $N$ & Intervention & Control & $\begin{array}{l}\text { Delirium } \\
\text { rate -intervention }\end{array}$ & $\begin{array}{l}\text { Delirium } \\
\text { rate-control }\end{array}$ & $p$ value \\
\hline Wibrow 2022 [8] & $\begin{array}{l}\text { Multi-center } \\
N=847 \text { mixed ICU patients }\end{array}$ & $\begin{array}{l}\text { Melatonin } \\
\quad 4 \mathrm{mg} \times 14 \text { days }\end{array}$ & Placebo & $147 / 419$ (35.1\%) & 138/422 (32.7\%) & 0.466 \\
\hline Ford 2020 [10] & $\begin{array}{l}\text { Multi-center } \\
N=210 \text { cardiac surgery }\end{array}$ & $\begin{array}{l}\text { Melatonin } \\
3 \mathrm{mg} \times 7 \text { days }\end{array}$ & Placebo & $21 / 98(21.4 \%)$ & $21 / 104(20.2 \%)$ & NR \\
\hline Abassi 2018 [9] & $\begin{array}{l}\text { Single-center } \\
N=172 \text { mixed ICU patients }\end{array}$ & $\begin{array}{l}\text { Melatonin } \\
5 \mathrm{mg} \times 5 \text { days }\end{array}$ & Placebo & $3 / 67$ (4.5\%) & $1 / 70(1.4 \%)$ & 0.36 \\
\hline Vijaya-kumar 2016 [13] & $\begin{array}{l}\text { Single-center } \\
N=56 \text { Organo-phosphate } \\
\text { poisoning patients }\end{array}$ & $\begin{array}{l}\text { Melatonin } \\
3 \mathrm{mg} \times \mathrm{ICU} \text { stay }\end{array}$ & Placebo & $13 / 26(50 \%)$ & $26 / 30(85 \%)$ & $<0.001$ \\
\hline Nishikimi 2018 [12] & $\begin{array}{l}\text { Single-center } \\
N=88 \text { mixed ICU patients }\end{array}$ & $\begin{array}{l}\text { Ramelteon } \\
8 \mathrm{mg} \times \mathrm{ICU} \text { stay }\end{array}$ & Placebo & $11 / 45(24.4 \%)$ & 20/43 (46.5\%) & 0.044 \\
\hline Hatta 2014 [11] & $\begin{array}{l}\text { Multi-center } \\
N=67 \text { mixed medical hospital } \\
\text { and ICU patients } \geq 65 \text { years }\end{array}$ & $\begin{array}{l}\text { Ramelteon } \\
8 \mathrm{mg} \times 7 \text { days }\end{array}$ & Placebo & 1/33 (3\%) & $11 / 34(32 \%)$ & 0.003 \\
\hline
\end{tabular}

$N R$ not reported

quality about trial interventions, including a clear rationale for the melatonin dose selection, protocol compliance checks, and serum melatonin concentrations measured in a subset of patients. Key limitations in performing a prevention trial include difficulties to confirm negative delirium status pre-enrollment, early in ICU stay in the setting of sedation, coma, and mechanical ventilation. Therefore, the authors took a pragmatic approach to enrollment and planned an a priori analysis based on initial delirium status. The PRISMA diagram highlights challenges with delirium screening early in the ICU admission with $17 \%$ excluded due to "not expected to improve within 14 days to perform CAM-ICU" or "preceding reason could not perform CAM-ICU”. Approximately $9 \%$ of subjects enrolled had initial delirium assessment as positive. Also, while the sample size calculations attempted to account for anticipated missing or non-assessable delirium assessments that are commonly experienced in ICU practice, the amount missing was higher than projected with $\sim 17 \%$ missed time points in both arms. Although the authors reported exposures to sedatives and analgesics that may impact delirium burden in both arms, sedation and ventilator weaning protocols [9], that are known to impact delirium or coma burden in ICU, were not standardized in participating centers. Other environmental factors that may impact melatonin activity or sleep quality such as eye mask and ear plugs to modify exposure to light and noise, were rarely used.

Should the results of the Pro-MEDIC trial lead clinicians to abandon melatonin for delirium prophylaxis in ICU? The data are certainly compelling, yet other multicenter trials are ongoing (NCT03524937, NCT02615340, NCT03013790, NCT047216913). Previous randomized trials that explored the use of melatonin or melatonin receptor agonists for delirium prophylaxis in the ICU found mixed results (Table 1) [10-14]. We often think simple things will fix complicated problems in the ICU; they rarely do. Of note, we have not yet found any single prophylactic drug that acts on a specific pathway to prevent delirium consistently [7]. What we do know is that bundled interventions (i.e., ABCDEF) reduce risk of delirium [15] showing us multifaceted approaches are likely key. One of the next important steps in delirium research may include studies investigating specific pharmacological interventions such as melatonin to restore sleep layered on top of bundled interventions that have been proven successful. These studies should not only focus on delirium burden in ICU, but also other clinically relevant outcomes including cognitive disturbances, anxiety and depression, and sleep disorders that are frequently observed in ICU survivors [16].

\section{Author details \\ ${ }^{1}$ Departments of Pharmacy and Medicine, Mount Sinai Hospital, Toronto, Canada. ${ }^{2}$ Leslie Dan Faculty of Pharmacy, University of Toronto, Toronto, Canada. ${ }^{3}$ INSERM UMR1 148, team 6, Université de Paris, 75018 Paris, France. ${ }^{4}$ Intensive Care Medicine, AP-HP, Hôpital Bichat - Claude Bernard, 75018 Paris, France. ${ }^{5}$ Critical Illness, Brain Dysfunction, and Survivorship (CIBS) Center, Vanderbilt University Medical Center, Nashville, TN, USA. ${ }^{6}$ Division of Allergy, Department of Medicine, Pulmonary, and Critical Care Medicine, Vanderbilt University Medical Center, Nashville, TN, USA. ${ }^{7}$ Geriatric Research, Education and Clinical Center (GRECC) Service, Nashville Veterans Affairs Medical Center, Tennessee Valley Healthcare System, Nashville, TN, USA.}

\section{Declarations}

\section{Conflicts of interest}

LB is the principal investigator of the MELLOW trial (NCT02615340) which is supported by grants from the University of Toronto and Canadian Critical Care Trials Group. RS received grants from the French Ministry of Health. RS is member of the scientific committee of the DEMEL trial (NCT03524937) and 
the principal investigator of the R2D2 trial (NCT04273360). EWE has ongoing funding from the NIH and the Veteran's Affairs.

\section{Publisher's Note}

Springer Nature remains neutral with regard to jurisdictional claims in published maps and institutional affiliations.

Published: 7 March 2022

\section{References}

1. Ely EW, Shintani A, Truman B, Speroff T, Gordon SM, Harrell FE Jr, Inouye SK, Bernard GR, Dittus RS (2004) Delirium as a predictor of mortality in mechanically ventilated patients in the intensive care unit. JAMA 291:1753-1762

2. Pandharipande PP, Girard TD, Jackson JC, Morandi A, Thompson JL, Pun BT, Brummel NE, Hughes CG, Vasilevskis EE, Shintani AK, Moons KG, Geevarghese SK, Canonico A, Hopkins RO, Bernard GR, Dittus RS, Ely EW (2013) Long-term cognitive impairment after critical illness. N Engl J Med 369:1306-1316

3. Arendt J (2005) Melatonin: characteristics, concerns, and prospects. J Biol Rhythms 20:291-303

4. Marra A, McGrane TJ, Henson CP, Pandharipande PP (2019) Melatonin in critical care. Crit Care Clin 35:329-340

5. Dessap AM, Roche-Campo F, Launay JM, Charles-Nelson A, Katsahian S, Brun-Buisson C, Brochard L (2015) Delirium and circadian rhythm of melatonin during weaning from mechanical ventilation: an ancillary study of a weaning trial. Chest 148:1231-1241

6. Oxlund J, Knudsen T, Strom T, Lauridsen JT, Jennum PJ, Toft P (2021) Serum melatonin concentration in critically ill patients randomized to sedation or non-sedation. Ann Intensive Care 11:40

7. Burry LD, Cheng W, Williamson DR, Adhikari NK, Egerod I, Kanji S, Martin CM, Hutton B, Rose L (2021) Pharmacological and non-pharmacological interventions to prevent delirium in critically ill patients: a systematic review and network meta-analysis. Intensive Care Med 47:943-960

8. Wibrow B, Martinez FE, Myers E et al (2022) Prophylactic melatonin for delirium in intensive care (Pro-MEDIC): a randomized controlled trial. Intensive Care Med. https://doi.org/10.1007/s00134-022-06638-9
9. Girard TD, Kress JP, Fuchs BD, Thomason JW, Schweickert WD, Pun BT, Taichman DB, Dunn JG, Pohlman AS, Kinniry PA, Jackson JC, Canonico AE, Light RW, Shintani AK, Thompson JL, Gordon SM, Hall JB, Dittus RS, Bernard GR, Ely EW (2008) Efficacy and safety of a paired sedation and ventilator weaning protocol for mechanically ventilated patients in intensive care (Awakening and Breathing Controlled trial): a randomised controlled trial. Lancet 371:126-134

10. Abbasi S, Farsaei S, Ghasemi D, Mansourian M (2018) potential role of exogenous melatonin supplement in delirium prevention in critically ill patients: a double-blind randomized pilot study. Iran J Pharm Res 17:1571-1580

11. Ford AH, Flicker L, Kelly R, Patel H, Passage J, Wibrow B, Anstey M, Edwards M, Almeida OP (2020) The healthy heart-mind trial: randomized controlled trial of melatonin for prevention of delirium. J Am Geriatr Soc 68:112-119

12. Hatta K, Kishi Y, Wada K, Takeuchi T, Odawara T, Usui C, Nakamura H (2014) Preventive effects of ramelteon on delirium. JAMA Psychiat 71:397

13. Nishikimi M, Numaguchi A, Takahashi K, Miyagawa Y, Matsui K, Higashi M, Makishi G, Matsui S, Matsuda N (2018) Effect of administration of ramelteon, a melatonin receptor agonist, on the duration of stay in the ICU: a single-center randomized placebo-controlled trial. Crit Care Med 46:1099-1105

14. Vijayakumar HN, Ramya K, Duggappa DR, Gowda KV, Sudheesh K, Nethra SS, Raghavendra Rao RS (2016) Effect of melatonin on duration of delirium in organophosphorus compound poisoning patients: a doubleblind randomised placebo controlled trial. Indian J Anaesth 60:814-820

15. Pun BT, Balas MC, Barnes-Daly MA, Thompson JL, Aldrich JM, Barr J, Byrum D, Carson SS, Devlin JW, Engel HJ, Esbrook CL, Hargett KD, Harmon L, Hielsberg C, Jackson JC, Kelly TL, Kumar V, Millner L, Morse A, Perme CS, Posa PJ, Puntillo KA, Schweickert WD, Stollings JL, Tan A, D'AgostinoMcgowan L, Ely EW (2019) Caring for critically ill patients with the ABCDEF bundle. Crit Care Med 47:3-14

16. Rose L, Burry L, Agar M, Campbell NL, Clarke M, Lee J, Marshall JC, Devlin JW, Blackwood B, Needham DM, Siddiqi N, Page V, Del CG (2021) A core outcome set for research evaluating interventions to prevent and/or treat delirium in critically ill adults: an international consensus study (DelCOrS). Crit Care Med 49:1535-1546 